\title{
АЛКОГОЛІЗМ У ПІДЛІТКІВ ЯК ВАЖЛИВА МЕДИКО-СОЦІАЛЬНА ПРОБЛЕМА
}

\author{
I. В. Лисюк
}

\author{
Конотопське медичне училище
}

У статті проаналізовано основні чинники розвитку підліткового алкоголізму в Україні та розроблено систему педагогічних заходів із метою психологічної профілактики вживання алкоголю серед молоді, які рекомендується використовувати в роботі кураторів студентських груп.

\section{ALCOHOLISM AMONG ABOLESCENTS AS AN IMPORTANT MEDICAL AND SOCIAL PROBLEM}

\author{
I. V. Lysyuk
}

\section{Konotop Medical School}

The article analyzes the main factors of teenage alcoholism in Ukraine and the system of educational activities to psychological prevention of alcohol use among young people which are recommended for the curators of student groups.

Вступ. Алкоголізм - це тяжка хронічна хвороба, яка здебільшого складно лікується. Вона розвивається за рахунок регулярного й тривалого вживання алкоголю та характеризується особливим станом організму: нестримним потягом до алкоголю й деградацією особистості. Проблема алкоголізму серед підлітків $\epsilon$ дуже актуальною, адже Україна, за результатами опитування Всесвітньої організації охорони здоров'я (ВООЗ), посідає перше місце в списку серед інших країн за рівнем уживання алкоголю серед неповнолітніх. Підлітковий алкоголізм дуже небезпечний, тому що призводить до значних фізичних руйнацій несформованого організму, до розвитку тяжких психічних захворювань; збільшує кількості девіантних учинків, скоєних підлітками та більш тяжких протиправних дій; підлітковий алкоголізм складніше вилікувати, ніж алкоголізм у дорослих; він призводить до погіршення подальшої соціальної адаптації та соціальної деградації молодої людини.

Мета роботи: аналіз основних чинників розвитку підліткового алкоголізму в Україні та розробка системи педагогічних заходів із метою психологічної профілактики вживання алкоголю серед молоді, які рекомендується використовувати в роботі кураторів студентських груп.

(C) І. В. Лисюк, 2016
Основна частина. В Україні спостерігається високий рівень вживання алкоголю підлітками та студентською молоддю, що безпосередньо є соціально-демографічною проблемою, яка стосується всього населення [1].

Алкоголізм у молодому віці спостерігають набагато частіше, ніж у зрілому віці. Причина в тому, що, наприклад, підлітки є соціально незрілими, більш схильні до впливу алкоголю. Їх організм чутливіший і тому ризик стати алкоголіком дуже високий [2].

Інформаційно-освітні заходи профілактики в Україні не дають очікуваного результату, тому що нав'язлива реклама, відносно доступні ціни, особистий приклад тих, хто за характером роботи має справу з дітьми та підлітками, а також «мода» на алкоголь призводить до зниження віку споживачів алкоголю.

На сьогодні рівень споживання алкоголю в Україні $\epsilon$ одним із найвищих у світі й становить близько 12-13 літрів абсолютного спирту на душу населення за рік (неофіційна статистика повідомляє про 20 л). Понад 40000 українців щороку помирають від надмірного вживання алкоголю. Відомо, що пиво є перехідним алкогольним напоєм для молоді, які пізніше починають вживати щось міцніше. Виявляється, що 22 \% українських підлітків почали вживати алкоголь ще до 13 років [4]. 
За даними статистики, в останні роки відсоток підлітків із діагнозом «алкоголізм» у віковій групі 12-16 років склав $5 \%, 17-25$ років - $10 \%$, причому багато хто з них вперше спробували алкогольні напої ще в дитинстві, в 8-9 років. Встановлено, що 90 \% учнів до закінчення школи відчували стан сп'яніння [3].

У всесвітньому масштабі 5 \% усіх смертей серед молоді віком від 15-29 років викликані вживанням алкоголю. У Європі щороку з причин, зумовлених алкоголем, помирає близько 55000 молодих людей. У цілому світі від алкогольної залежності страждають 140 млн людей, в Україні це близько 1 млн.

Отже, серед основних чинників зростання рівня вживання алкоголю можна виділити такі:

- інформаційний - збільшення пропаганди вживання алкоголю серед молоді через неконтрольовану рекламу чи інші інформаційні продукти (телебачення, інтернет, зовнішня реклама на бігбордах), які показують алкогольні напої як неодмінний атрибут будьякого відпочинку і розваг, закликаючи до веселого «пивного» способу життя;

- соціальний - вплив соціального оточення (навчальний заклад, вулиця, товариство), в якому підліток прагне виділитися або, навпаки, бути «як всі», що зрештою призводить до того, що вся компанія підлітків починає вживати алкоголь;

- особистісно-психологічний - недостатньо сформований світогляд молодої особи щодо розуміння здорового способу життя, відсутність належних моральних цінностей, які допомагають вибирати конструктивну життєву позицію, зумовлюють розвиток підліткового алкоголізму. Невдачі в житті психологічно вразливого та соціально незрілого підлітка, розчарування, невміння раціонально використовувати вільний час $\epsilon$ сприятливим фоном для вирішення проблем «подорослому», оманливого самоствердження, підвищення самооцінки молодої людини або ж їі данини сучасній «моді».

Поряд із медичними, адміністративними та юридичними заборонами слід здійснювати систематичну профілактику вживання алкоголю серед молоді, при цьому, потрібно, насамперед, спиратися на психологічний, особистісний фактор. Далі перейдемо до педагогічних заходів профілактики досліджуваної проблеми.

Отже, профілактична програма повинна включати певні види діяльності за такими напрямками:

- поширення інформації про причини, форми і наслідки зловживання алкогольними напоями;
- формування у підлітків навичок аналізу і критичної оцінки інформації, що отримується про алкоголь, і вміння приймати правильні рішення;

- надання альтернативи вживанню алкоголю.

На основі дослідження та вивчення ролі куратора групи в профілактиці алкоголізму серед підлітків рекомендуємо:

1) провадити навчальну програму щодо протидії вживання алкоголю саме підлітками. Розширити та поглибити їі;

2) із залученням елементів педагогіки, що ґрунтуються на особистому досвіді, інтерактивних, рухливих та рольових іграх, в індивідуальних та групових бесідах слід навчати підлітків форм та стилів подолання життєвих проблем;

3) здійснення супервізії та надання підтримки всім, хто працює над впровадженням антиалкогольних профілактичних програм та здійснює розробку матеріалів для різних цільових груп, передача наукового та практичного досвіду із попередження вживання алкоголю викладачам, педагогам-організаторам, батькам;

4) передача функцій ведучого програми до рук підлітків (попередньо підготувавши їх), виходячи із принципу, що підлітки набагато ближче до специфічного повсякденного світу своєї групи, в якій впроваджується програма;

5) профілактика вживання алкогольних напоїв підлітками повинна передбачати роботу не тільки $з$ дітьми, але й з їх батьками, вчителями, тобто профілактична робота повинна бути комплексною і впливати не лише на підлітка, а й на його оточення;

6) під час проведення профілактичних занять забезпечити соціальну підтримку підлітків, контролювати реалізацію розробленої програми, консультувати по питаннях, що цікавлять учасників програми;

7) конкурс студентських презентацій на теми: «Захисти свою позицію», «Орієнтація на мотивацію ведення здорового способу життя», «Особистісна орієнтована модель формування в учнів і студентів навичок здорового способу життя», «який спосіб життя - таке й здоров'я»;

8) лекції, бесіди із студентами на теми: «Відповідальність неповнолітніх перед законом», «Тверезість норма життя», «Алкоголь і здоров'я», «Охорона громадського порядку - обов'язок кожного. Законодавство про боротьбу з пияцтвом та наркоманією», «Від пияцтва до злочину - один крок», «Шкідливий вплив алкоголю на здоровий організм підлітка»; 
9) зустрічі студентів з медичними працівниками щодо профілактики алкоголізму; з дільничними інспекторами щодо відповідальності за розпиття алкогольних напоїв;

10) профілактичні рейди в гуртожитку та інші місця проживання й дозвілля студентів;

11) фестивалі художньої творчості, конкурси творчих робіт: «Я обираю життя», «Молодь обирає здоровий спосіб життя»;

12) книжкові виставки, конкурси малюнків, плакатів, листівок, буклетів із відповідної тематики;

13) проведення тематичних виховних годин у групах;

14) перегляди відео- та кінофільмів;

15) розробка студентами проектів соціальної реклами (слогани, малюнки) щодо неприпустимості алкоголізму, а, навпаки, пропаганди здорового стилю життя.
Висновок. За результатами дослідження, ми визначили, що основними факторами розвитку підліткового алкоголізму є: інформаційний (мас-медіа, зовнішня реклама), соціальний (середовище проживання, навчання та дозвілля студента, негативний приклад дорослих) та особистісно-психологічний (вразливість підліткової психіки, недостатньо сформовані чи нестійкі моральні цінності та переконання щодо відповідальності за власне духовне і фізичне здоров'я, особистісну значущість у суспільстві).

Рекомендовані практичні поради щодо педагогічного впливу на підлітків із метою профілактики алкоголізму спрямовані на розумове, моральне виховання студентів, розвиток їх творчих здібностей як учасників своєрідного руху за тверезий здоровий стиль життя.

3. Хрещатик. - 2014. - № 135 [Електронний ресурс]. Режим доступу : URL: http://www.kreschatic.kiev.ua/ ua/4535/art/1410980038.html

4. Ягодинський В. В. Профілактика негативних явищ серед учнівської та студентської молоді / В. В. Ягодинський. - К. : Видавництво європейського університету, 2003. -168 c.

Отримано 16.08.16 